UDC 811,111

DOI https://doi.org/10.32841/2409-1154.2019.43.3.4

\author{
Mykhaylenko V. V., \\ Doctor of Philology, Professor, \\ Head of the Department of Translation and Philology \\ King Danylo University
}

\title{
THINK-ALOUD PROTOCOL IN TRANSLATION: A PILOT PROJECT
}

Summary. Think Aloud Protocols (TAPs) are employed in various fields (e.g., teaching, nursing, computer programming [see also 21]) to reveal the process aimedata better understanding the outcome. Think-aloud-based translation process research emerged in the mid-1980s wherein participants are requested to speak out their thoughts - the normal thought processes of translators - while translating a text [see the bibliography: 8, p. 105] and developing students' self reflection. When a translator is asked how s/he is translating, in response you can hear that $\mathrm{s} /$ he knows languages, but it is far from being true. There is an argument that there is no strong evidence suggesting that TAP significantly changes or influences the translation process, though TAP's validity and completeness in a specific study might depend more or less on several variables. TAP and such recording methods as fastr eading, sight translation, self-and peer reviewing. as serve different specific research purposes, so they can be combined in a multimethod study to answer more complex research questions [22, p. 928]. This method allows data collection about the translator's thoughts at the same time he verbalizes them [3, p. 139]. The objective of this paper is fourfold: proces, product, academic and raising the efficieny of translation, additionally describtion and comparison of specific aspects of translation competence with data provided from a sight translation and a written translation task. The algorithm of TAPs, as a pilot experiment is elaborated. This is the the tentative introduction to the TAP in translation and we did not set the timing. There is an argument that TAP delayed translation by about $25 \%$; no significant effects on revision were found; thinking aloud forced translators to process text in smaller segments [9, p. 69]. But working in a team of professional translators using the TAP algorithm described we used to produce a lomger volume of translations which surpasses a volumeof individual translations - rare references to the dictionaries or encyclopedias, internet or telephone consultations with the national or international professionals in the field.

Key words: translation types, process, final product, algorithm, talkk-aloud protocol, translator, trainer, editor, expert, proofreader.

Preliminaries. Most studies of TAPs are addressed two perspectives: (I) translation as a process with the identification of causes of translation problems and strategies applied to solve them, and (II) translation as a product with the identification of of major content errors [1, p. 15]. The main objective of this article is to describe and compare specific aspects of translation competence with data provided from a sight translation (ST henceforth) and a written translation (WT henceforth) task. In order to achieve this objective we aim at identifying the following items in each translation modality: 1) Self-perceived causes of the problems. 2) How each particular problem is perceived to have been subjectively solved 3) Major translation errors. We assume that the translation process differs when performed at first sight or when it is written, therefore translation problems must be qualitative and quantitative different in each modality: Königs, for instance, mentions a number of types of actions that can be identified, such as macro-planning, identification of problems, solution of problems, associations, corrections, the use of dictionaries [10, p. 7-8], and Jääskeläinen (1993) is interested in the translator's focus of attention, comprising both problematic and unproblematic processing [8, p. 101f, cf 17, p. 17.]. Identification of problems, focus of attention, pauses, corrections and use of dictionaries are what might be called, surface phenomena, which can be noticed more or less easily, whereas macro-planning, solution of problems, associations and cultural transfer are more elusive.

Think-aloud protocol or'concurrent verbalization'refers to type of data collecting method, which is used in empirical translation processes earch.The transcripton of verbalization is called thinkaloud protocols (TAPs). Empirical studies of the translation process have used think-aloud protocols to provide a window into the mental activity which is not directly observable [19, p. 75]. This paper reports on a protocol study in a natural discourse situation involving two professional translators and discusses the relevance of the data to the debate on the use of verbalization as a methodology [see 12, p. 178]. These analyses have at least two pedagogical purposes: (I) The strategies observed in the TAPs may serve as models for successful translating. (II) If students training to become translators are used as subjects, TAPs may be used to find out where they have problems. The strategies observed in the TAPs may serve as models for successful translating [13, p. 146; 8, p. 101; 11, p. 66;12] in a teamwork of a big translation company.

State of the Arts. The Think-aloud protocol provides evidence of translation strategies and points to the need for a dynamic model of the translation process that takes into account activation, suppression, and attending mechanisms. The issue of distinguishing between translation as product or as process shows that dealing with text as product entails understanding the process that ultimately leads to this product creation."The distinction cannot give the scholar leave to ignore the self-evident fact that the one is the result of the other, and that the nature of the product cannot be understood without a comprehension of the nature of the process" (Holmes). But one question that constantly surfaces in the literature is whether TAP has an influence on the translation process and alters the cognitive processes [e.g. 7, p. 1;22, p. 929]. The theory that verbal protocols can be used to elicit data on cognitive processes was proposed by Ericsson and Simon, and they have provided substantial empirical support for it [5].

There used to be two lines of TAP-based translation process research. One is translation process research proper, which aims to identify characteristics of successful translation processes and to 
understand translation competence acquisition process. The other concerns research methodology, including the validity of the thinkaloud method, subject choice (students, bilinguals or professionals), dialogue vs. monologue, between-subjects vs. within-subjects designs, protocol analysis method and others. In her widely read review, Bernardini mentions that "a major problem with TAP studies has been the lack of an established research paradigm, resulting in a rather loose treatment of methodological issues (research design, data analysis, research report" [2, p. 251].

Think-aloud protocols are beset by a number of theoretical problems that must be figured into any use made of their data. Verbalization won't register unconscious fac-tors and automatic processes, and it can change a mental activity instead of simply reporting it. Similarly, subjects are sometimes instructed to provide specific kinds of information: description, for instance, without any justification [see 24].

TAPs represent recent research trends in the field of translation that stand out over the last three decades. It is a new trend in the sense that it is process-oriented, rather than the prescriptive product-oriented, aiming at providing reliable models for data collection and analysis in translation studies. The frequency of strategies used in WT. involving causes and strategies used to solve any particular problem. That is, any particular translation problem has been found to respond to different causes for different subjects. The most frequent cause for problems was a deficiency in linguistic understanding. A skill of the bilingual sub-competence. The sample considered this as the major cause for translation problems in consistence with Lörscher experimental results [13]. Answers like "The equivalent I was looking for did not spring up to mind" "I haven't read ahead enough" or "I have misread a word" have a cognitive component. The latter two are more specifically associated to fast and efficient reading. They are part of the psycho-physiological components. Such causes of problems have not surfaced in written translation. It must be hard to deviate from the source text form and have problems to reshape the target text belong to the translation knowledge subcompet ence. TAP-based translation process research has a relatively short history. Most of the responders in the survey believe that it has potential for interesting insights into translation-related cognitive processes. There is a need to find out what goes on in the translator's mind, a means to get a glimpse into the "black box" [see 18]. Yet many of the scholars have mentioned their doubts and difficulties in using TAP.

Strategies of the Experiment: Organization. To undertake an experiment I planned to invite:

a trainer to moderate the students'performance and summing up the experiment with his/her comments;

an expert in a TT definite professonal discourse who would express his expertise - whether the product meets the Ukrauinian rules - distribution, functional semantics, and ordering;

a proof-reader to improve syntax, style, and interference of English in the final Ukrainian text;

From my university Interpreting Class I have invited three graduates majoring in English-Ukrainian translation to venture in the experiment, which they have not done it yet, but expressed their endowment.

And then I specified the end-goals of the experiment, pinpointed the rolels of the students. Notwithstanding, the students were specializing in the professional legal translation and interpreting they had to sit for the Oxford Placement test, which provides a reliable an efficient means for placing students at the start of the experiment for the trainer to select an appropriate text for their translation. The test has been notwithstanding by the Common European Framework of languages: Learning, Teaching, Assessment (commonly known as CRF).

In the language lab there is a smart board with the text projected on it, the prerformance is recorded; students comfortably seated in the High-Back Executive swivel chairs. The trainer keeps conspicuous not to distract the students' attention from translation and if there are booths for conference interpreting in the lab the editor and the proof-reader must be sitted in them.

Algorythm of the Experiment. We have elaborated the TAP algorithm on the basis of different strategies:

(I) The students are asked to perform an orally-produced translation of a written source text projected onto thescreen, i.e. the sight translation without a preliminary scanning, skipping, and skimming the text [cf. the technology: 25, p. 1379; 16, p. 387-389]. Consequently, the students cannot know the topic of the text, the key words, and the cohesive meansof the text; (II) If they meet a difficulty in translating a word or a phrase each student is asked to supply his/ her variant whatever springs to his/her mind. (III) They are asked to explain why they have chosen it; (IV) At the same time when they are producing their translations orally, the students are asked by the trainer "the translators themselves to reveal their mental processes in real time while carrying out a translation task [2, p. 242]; (V) At the end of the oral interpreting the text the trainees are welcome to exchange critical remarks of their own interpreting; (VI). Then there is a peer analysis of the translation; (VII) The trainer gives a contrastive analysis of the ST and the students' rough copy with all suggested variations; (VIII) The editor gives hi/her review of language and cultural differences between the ST and the TT, especially in the field of a distribution, style, and ordering in the phrases and the sentences. (IX) The proofreader has been recording the translation and presents the first variant. $(\mathrm{X})$ The final copy must be perfected by the trainer together with the students and a bilingual (SL + TL) professional in the area discribed in the text.

Here is a tentative introduction to theTAP in translation, therefore we did not set the timing. To make the translation more efficient (1) the sudents' classes in fast reading and sight translations must directed to intensive practice [see 23, p. 97; 14, p. 49]; (2) an introduction of students to professional discourse in SL and TL is necessary to make their translation morecoherent and cohesive/; (3) to stipulate students' anticipation.

There is an argument that TAP delays translation by about $25 \%$; and no significant effects on revision were found; thinking aloud forced translators to process text in smaller segments [9, see also 20, 108-109]. But working in a team of professional translators employing the TAP algorithm described we used to produce a lomger volume of translations which surpasses a volume of a sum of translations by individual translators, besides rare references to the dictionaries or encyclopedias, internet or telephone consultations with the national or international professionals in the field [see 15, p. 49].

The interlanguage concept is also implied in Königs' observation of learner-induced one-to-one correspondencies [10, p. 168f], a notion which he uses to explain unsuccessful processes. Some scholars use psycholinguistic notions of the comprehension process, namely frames, scripts and schemes as well as bottom-up and top-down processes when analysing consecutive and 
simultaneous interpretation [12, p. 177-178]. Königs, for instance, mentions a number of types of actions that can be identified, such as macro-planning, identification of problems, solution of problems, associations, corrections, the use of dictionaries [10, p. 7f].

There are some other activities proposed by Gerloff (1986) who defines text processing strategies as any metalinguistic or metacognitive comments made or specific problem-solving behaviors affected, during the decoding and rendering of the translation text [6, p. 243]. The strategies she suggests are: 1 . Problem identification 2. Linguistic analysis 3. Storage and retrieval 4. General search and selection 5. Text inferencing and reasoning 6. Text contextualization 7. Task monitoring [6]. Some other strategies: making analogies with other L2 words, using knowledge about word formation; using knowledge about typographical conventions; looking for similarities with L1; using knowledge about punctuation; and analyzing textual organization and text type. The strategies found during an experiment can be classified as the following: 1. Using Imagery; 2. Look-up; 3. Contextual recourse, 4. Analyzing and reasoning; 5. Resourcing; 6. Self-Recourse 7. Contextual recourse 8.Deductive reasoning; 9. Inductibve inferencing; 10. Co-text recourse, 11. Switching to L1; 12. Paraphrasing; 13. Problem-solving and 14. Other Compensation strategies [22, p. 930].

Findings and Perspective. The significance of our study is fourfold: investigatiom of the process, of the product, trining the future translators/interpreters, andtoraise the level of efficiency. Meantime, the TAPs think aloud protocolsisa an actual instrument for training students to overcome their uncertainty in translation/ interpreting. Besides, a team of translators including experts, an editor, and a proof reader is much more effective than an individual translator in timing and a volume of the translated texts. The prvious publications had a twofold objective to consider the TAP as a process and a product. Theoretically, the findings of this study will contribute to the mainstream TAP research in general and TAP in translation studies in particular. Though much has been written on TAP studies in different genres and different groups of students, we are still far from a unified body of literature in the field. This and other similar studies can help the development of a more unified theory of the application of TAP in translation studies in general and professional discourse registers in particular with a much more cognitive orientation. Practically, one of the most significant purposes of TAP studies in general and translation in particular is to extract and delve into the processes through which the act of translation and interpretation can be much more convenient.

Think aloud protocols have been used for decades as a method for eliciting the activity which is occurring in a translator's mind. In this study think aloud protocols have been used not only as a data collecting method but also as a technique for training translators. The findings of this study and similar studies can give a good image to learners and teachers to have a more vivid picture of the translation process and will show them how to avoid the use and application of incorrect and demanding strategies in their translation processand how to make the process efficient and the product reliable.

\section{References:}

1. Bahameed A.S. Think-aloud protocols: Translating proverbs. London : Sayyab Books, 2009. 78 p.

2. Bernardini S. Think-aloud protocols in translation research: Achievements, limits, future prospects. Target. 2002. Vol. 13. Issue2. P. 241-263.
3. EftekharyA.A., Aminizadeh S. Investigating the use of thinking aloud protocols in translation of literary texts. Theory and practice in language studies. Vol. 2. № 5. P. 1039-1047.

4. Ericsson K. Anders. Protocol analysis and expert thought: Concurrent verbalizations of thinking during experts' performance on representative tasks / ed. K. Anders Ericsson et al. The Cambridge handbook of expertise and expert performance. Cambridge: CUP, 2006. P. 223-241

5. Esfahani M.J.B. Constructivism translation trainingin translation process workshops: The effect of Think-aloud protocols in increasing student uncertainty management. Inter-l Journ-l Business and Social Sciences. 2015. № 5 (1). P. 82-92.

6. Gerloff P. Second language learners reports on the interpretive process: Talk-aloud protocols of translation' / ed. J. House, S. Blum-Kulka. Interlingual and Intercultural Communication. Tübingen : Gunter Narr, 1986. P. 243-246.

7. Hansong Cai. The Application of the Verbal Protocol Method in the Study of Translating Process. Shanghai Technical Translation. 2000. Vol. 3. P. $1-4$

8. Jääskeläinen Riitta. Think-aloud protocol studies into translation: An annotated bibliography. Target. 2002. Vol. 14 (1). P. 107-136.

9. Jakobsen Arnt L. Effects of think aloud on translation speed, revision, and segmentation / ed. Fabio Alves. Triangulating translation: perspectives in process oriented research. Amsterdam : John Benjamins, 2003. P. 69-95.

10. Königs F.G. Processus mentaux étudiés chez des sujets allemands apprenant le français lorsqu'ils sont en train de traduire. Meta. 1996. № 41 (1). P. 7-25.

11. Krings H.P. Translation problems and translation strategies of advanced German learners of French (L2). / ed. J. House \& S. BlumKulka. Interlingual and Intercultural Communication. Tübingen : Gunter Narr, 1986. P. 263-275.

12. Kussmaul P., Tirkkonen-Condit S. Think-Aloud Protocol Analysis in Translation StudiesTraduction. Terminologie et Redaction. 1995. Vol. 8 (1). P. 177-199.

13. Lörscher W. Translation Performance, Translation Process, and Translation Strategies. A Psycholinguistic Investigation. Tübingen : Gunter Narr, 1991. 307 p.

14. Mykhaylenko V.V. Sight translation: training algorithm. Scientific Journal of the Lviv State University of Life Safety Philolog-l Periodical of Lviv. 2017. № 1. P. 49-54.

15. Mykhaylenko V.V. Viable technologies in teaching register-based translation/interpreting. Науковий вісник Херсонського держ. університету. Серія «Германістика та міжкультурна комунікаиія». 2017. C. $49-53$.

16. Mykhaylenko V.V., Bakhov I.S. Glossary of applied linguistics. Kyiv: MAUP, 2019. $545 \mathrm{p}$

17. Picken Catriona (ed.). ITI Conference 7 Proceedings. London: Institute of Translation and Interpreting. 1994. P. 130-142.

18. Pöchhacker Franz. Interpreting studies. London, New York : Routledge, 2004. $252 \mathrm{~s}$.

19. Séguinot Candace. Some thoughts about think-aloud protocols. Target. 1996. Vol. 8 (1). P. 75-95.

20. Shahrokh Mohsen The effect of think-aloud on the amount of translation Revision, Inter-l Journal of English Language and Translation Studies. 2016. Vol. 4 (4). P. 108-119.

21. Smith A. Think aloud protocols: Viable for teaching, learning, and professional development in interpreting. Inter-l Journal of transl. and interp. 2004. № 6 (1). P. 128-143.

22. Sun S. Think-aloud-based translation process research: Some methodological considerations. Meta. 2011. Vol. 56. № 4. P. 928-951.

23. Temizoz O. Eyetracking Directionality in the Translation Process: A Pilot Study. Journal of Translation Studies. 2016. P. 97-122.

24. Venuti Lawrence (ed.). The translation studies reader. London / New York : Routledge, 2000. 539 p.

25. Zhou Yali, Lin Yan. Probe into Translation Process Based on Thinkaloud Protocols. Theory and Practice in Language Studies. Vol. 2. 2012. № 7. P. 1376-1386. 
Михайленко В. В. Переклад як процес і продукт (ТАР): пілотний проект

Анотація. Протокол перекладу й обговорення (ТАР) використовується в різних сферах (наприклад, у навчанні, сестринській справі, комп'ютерному програмуванні), щоб виявити процес, спрямований на краще розуміння результату. Дослідження перекладацького процесу на основі обговорення беруть свій початок у середині 1980-х рр., коли учасникам запропонували висловити свої думки під час перекладу тексту [див. 8] та розвитку саморефлексії учнів [23]. Коли перекладача запитують, як він перекладає, у відповідь ви можете почути, що він знає мови, але це далеко не правда. Немає жодних доказів, які свідчать про те, що ТАР суттєво змінює або впливає на процес перекладу, хоча дійсність і повнота TAP у конкретному дослідженні може залежати від кількох змінних. ТАР і такі методи, як редагування, інтерференція рідної мови, переклад з аркуша, швидкий перегляд тексту, читання зверху донизу слугують різним конкретним цілям дослідження [22, с. 928]. Завданням цього є тристороній процес, а також опис і порівняння конкретних аспектів компетенції перекладу з даними, наданими 3 візуального та письмового перекладу. Для досягнення цієї мети ми маємо визначити такі пункти у кожній мові перекладу: (I) самостійно сприйняті причини проблем; (II) як суб'єктивно вирішується кожна конкретна проблема; (III) основні помилки перекладу. Нами розроблено алгоритм ТАР як пілотний експеримент. ТАР сповільнює процес перекладу приблизно на 25\%; також не виявлено суттєвого впливу на сам переклад; мислення вголос змушує перекладачів обробляти текст у менших об'ємах [9, с. 2003]. Але команда професійних перекладачів, використовуючи зазначений алгоритм TAP, збільшує об'єм перекладів, що перевищує обсяг, підговлений окремими перекладачами. До того ж, не витрачається час на користування словниками й енциклопедіями, на інтернет або телефонні консультації 3 національними або міжнародними експертами у певній галузі.

Ключові слова: типи перекладу, процес, продукт, алгоритм, обговорення, перекладач, викладач, редактор, експерт, коректор. 